\title{
Challenges for the South African tourism industry to the year 2010 based upon a Delphi market research project
}

\author{
Jonathan Z. Bloom \& Marius Leibold \\ Department of Business Management, University of Stellenbosch, Stellenbosch 7600, Republic of South Africa
}

Received January 1994, accepted April 1994

\begin{abstract}
The South African tourism industry is expected to develop substantially over the next fifteen years, due to anticipated high tourism market growth rates. However, tourism demand is subject to a host of uncontrollable factors, which are difficult to measure and project. Despite this fact, the tourism industry of a country, including both private sector and public sector operators, needs scientifically accepted projection bases to make investment and other strategic decisions. In this article we aim to convey the results and recommendations of an empirical study based on the Delphi research model, and to indicate the implications thereof for future national tourism strategies of South Africa. The approach, methodology and techniques used in the research are relevant to researchers internationally, and the recommendations are useful for national tourism policy and strategy formulation in any geographical context.
\end{abstract}

Daar word verwag dat die Suid-Afrikaanse toerismebedryf aansienlik sal ontwikkel oor die volgende vyftien jaar as gevolg van hoër verwagte markgroeikoerse. Die toerismevraag is onderhewig aan 'n verskeidenheid onbeheerbare faktore wat moeilik is om te meet en te projekteer. Ongeag dié feit, benodig die toerismebedryf van ' $n$ land, wat beide die openbare en die private sektor insluit, ' $n$ wetenskaplike basis waarvolgens beleggings en ander strategiese besluite geneem kan word. In die artikel word die resultate en aanbevelings van 'n empiriese ondersoek, gebaseer op die Delphi-navorsingsmodel, verskaf asook die implikasies vir toekomstige nasionale toerismestrategieë vir Suid-Afrika. Die benadering, metodologie en tegnieke wat tydens die navorsing gebruik is, is relevant vir internasionale navorsers en die aanbevelings is waardevol vir die nasionale toerismebeleid en/strategieformulering binne enige geografiese verband.

\section{Introduction}

\section{Background to the research}

Against the background of far reaching political changes in South Africa over the past three years, windows of substantial opportunity are opening for the tourism industry in the subcontinent of Africa. This is reflected in the many positive changes which have taken place in the recent past. These include: the lifting of sanctions against South Africa in many key markets; new markets opening; increasing awareness of South Africa's potential as a key long-haul destination; increasing positive reporting on South Africa as a tourist destination, and closer co-operation and co-ordination with Southern African countries (Heath, 1992).

Before analyzing the local tourism industry, a global tourism overview is provided. At present tourism is the world's largest industry, with some observers contending that it has quadrupled in size over the last 25 years (Heath, 1992). According to the World Tourism and Travel Council (Heath, 1992), few industries have demonstrated such resilient and consistent growth in recent years. In reality, international travel and tourism generates approximately $\$ 3,5$ trillion in gross output. Total expenditure on domestic and international travel is estimated to represent $12 \%$ of the total World Gross National Product (Van Zyl, 1990).

In the international tourism context, South Africa is a small player with less than $0.25 \%$ of the international tourism market (Heath, 1992). However, the South African tourism industry is expected to develop substantially over the next five years, due to anticipated high tourism growth rates (Satour and Development Bank of South Africa, 1991).

South African foreign currency earnings from tourism were estimated to be between $\$ 1$ - billion and \$1,3-billion in 1992 ( $\$ 0.843$ billion in 1990 ) with a projected figure of $\$ 8$ billion by the year 2000 (Ryan, 1992). In quantitative terms it appears that the outlook is becoming increasingly positive with forecasts for the year 2000 indicating that with 1991 (521 257 tourists) as base year, overseas arrivals can virtually double by 1995 (966 000 tourists) and quadruple by the year 2000 (1 750000 tourists) (Heath, 1992).

Conveyed in the article are the results and implications of an empirical study based on the application of the Delphi technique. Due to the fact that information about the South African tourism industry is regarded by knowledgeable people as urgently lacking, this study makes a contribution by providing information on the projected future expansion of the tourism industry. This in turn should have implications for future national tourism strategies and policies.

\section{Forecasting demand in an unstable South African en-} vironment

Public and private sectors of the economy, who both contribute to tourism development, base decisions regarding the future of tourism in South Africa on anticipated social and political changes, and expected escalating demand for facilities from both domestic and international tourists. However, tourism demand is subject to a host of uncontrollable factors such as the degree of political stability, social tolerance and racial discrimination which are difficult to measure and project. A recent research report commissioned by the South African Tourism Board indicates that in the domestic tourism industry racial discrimination is still a problem (Woessner, 1992). Internationally the perception of South Africa as a country still applying racial discrimination in some form or other, is still reasonably strong according to a survey in a number of East European countries by the South African Broadcasting Corporation.

Kaynak \& Macaulay (1984) indicate that the forecasting of tourism demand requires assumptions regarding demographic and socioeconomic environments be explicitly formulated. In addition to this fact, the tourism industry of a country, includ- 
ing both private and public sector operators, need scientifically accepted projection bases to make investment and other strategic decisions.

Inadequate forecasting of tourism demand in South Africa in the past and present has, on both the domestic and international fronts, become a serious threat to the efficiency of operators in the tourism industry. However, the use of the correct technique or model in the appropriate situation to project demand will provide the concerned parties with valuable information regarding the planning and management of tourism, as well as effective resource allocation by the Government.

One qualitative technique which had been used with substantial success in the past for predicting tourism demand and potential is the Delphi research model, where convergence of expert opinion is the underlying criterion in an attempt to produce more precise projections (Kaynak \& Adacauby, 1984). The use of this model is to counter the limitations of traditional quantitative techniques and models. For example, it has been indicated in such studies that the Delphi technique is a suitable one to use when dealing with uncertainties in an area of imperfect knowledge.

\section{Nature and use of the Delphi technique}

The Delphi technique attempts to make constructive and systematic use of informed intuitive judgement. The Delphi method is unique in its method of eliciting and refining group judgement as it is based on the notion that a group of experts is better than one expert when exact knowledge is not available (Paliwoda, 1983). Delphi forecasting is basically a market research technique used to determine factors that will eventually alter the future of an industry. Historic data, conventional opinion surveys and focus groups cannot adequately determine these factors (Dull, 1988).

The Delphi technique was developed in the late 1940s by Rand Corporation, an independent think tank. Specifically, a small group of experts selected from a particular industry have to respond independently in a designated time frame to a problem scenario. After each round, the information is consolidated and edited. Unlike focus groups, the respondents do not converse with the other study participants, but they are given feedback from the other respondents after each set of questions.

The objective is to narrow the answers of the respondents at each phase of questioning so that a consensus can be reached during the final phase. The value of the Delphi technique is that it uses experts who would normally be rejected from research. Separating the respondents cuts down the bias and prevents the domination of group opinion by personality or reputation. The salient features of the process are anonymity, controlled feedback, group response and conscious striving towards consensus.

There are two underlying assumptions upon which the Delphi technique is based (Jolson \& Rossow, 1971). First, with repeated measurement, the range of responses will decrease with convergence towards the mid range of the distribution. Second, the total groun response, or median, will successively move toward the 'correct' or 'true' or the 'most likely' answer. Some authors emphasize that the Delphi technique is used to generate rather than test hypotheses, to map out a field rather than to test relationships within it (Kaynak \& Macaulay, 1984).

As with the Delphi model, Gearing-Swart-Var's (GSV) technique apparently has tremendous potential for application in the tourism area (Gearing, et al., 1976). In the same way as the Delphi model, this technique relies on expert opinion but does not seek expert consensus.

\section{Delphi study - a recognized approach to qualita- tive forecasting}

Various qualitative methods exist to gather judgements of a group of experts. First, the 'jury of executive opinion', where people meet as a committee during which communication is encouraged to arrive at a group estimate (Chambers, et al., 1975). For example, BarOn (1979) applied this technique in Thailand to arrive at alternative assumptions regarding the environment for international tourism. Secondly, the pooled individual estimate method requires experts from each segment, such as public policy makers, industry operators, etc., to supply separate estimates to a project leader, who pools the data. A third method is the Delphi technique which has become a popular method for developing tourism market scenario's and forecasts.

In the leisure, recreation and tourism field, many applications of the Delphi technique in forecasting the future environment have been reported in the literature. One such study is by Dyck \& Emery (1970), where six panels, each addressing a different subject area, were formed to forecast the future distribution of work and leisure time and the most likely use of this leisure time in Alberta, Canada. Two rounds of questionnaires were conducted and the final results were summarized to provide forecasts, dates and trends.

A more recent Delphi study was carried out by Kaynak \& Macaulay (1984) in measuring the tourism market potential of Nova Scotia. The two-round study concluded that: value changes would not have major effects on Nova Scotian society and neither on tourism development, and seemingly little change in the structure of the tourism industry would occur, but if it occurred it would positively impact on future tourism development.

In addition, Yong (et al., 1988) have used a two stage procedure to determine a future environmental scenario and the factors which will allow Singapore to compete successfully in the international tourism market. Other applications of the Delphi technique in leisure, recreation and tourism can be found in Ng (1984), Moeller \& Shafer (1983), Kibedi (1981), Edgell et al., (1980), Seely, et al., (1980), Uysal \& Crompton (1985) and Lavoie (1985).

Due to the many problems of gathering, interpretation, lack of consistency and variability of information needed to calibrate models, persons involved in policy making and planning may take resort to more simplified methods of data gathering. Judgements of individual experts are often used as surrogates for primary data gained from tourists. Kaynak \& Macaulay (1984) conclude that, "data sources are not only difficult to reach but the results are questionable at times'. Archer proposes a combination of the rigorous quantitative approach such as trend extrapolation with expert opinion as the most successful method of forecasting in the tourism field (Archer, 1980). 


\section{Advantages and limitations of the Delphi technique}

The use of the Delphi technique in tourism offers the following advantages:

- It can provide a useful way of identifying the questions critical to change in areas where conventional methodology is inadequate;

- Forecasting of likely tourism developments can be made relatively quickly and inexpensively;

- Different points of view, ranging from public policy makers to private industry operators, are elicited and weighed in the process;

- If basic data are sparse or lacking, there may be no alternative than the Delphi technique.

The Delphi technique also offers certain limitations or disadvantages, (see e.g. Kaynak \& Macauly, 1984):

- So-called expert opinions are generally less satisfactory than hard facts;

- Responsibility is dispersed, and good and bad estimates are given equal weight; and

- The method is usually more reliable for aggregate forecasting of tourism trends than for developing reliable breakdowns by specific territory, customer groups (e.g. leisure, business, special interest) or product type (sightseeing, culture, adventure, sporting events, etc.).

Linstone \& Simmonds (1977) contend that the key weakness in Delphi has always been that certain questions are not asked - especially those that seem unimportant when beginning the study. Although the Delphi technique is generally considered an important advance worthy of continued use and development, it is nevertheless looked upon as a rather special and limited methodology for modelling future problems (Kaynak \& Macaulay, 1984). A further problem encountered in Delphi studies is a high drop- out rate which can be as high as 50\% per round (Lusch \& Laczniak, 1979).

One of the more recent innovations in the use of the Delphi technique is the 'Delphi Conference', in which the computer operates as real time accounting system of members' responses. This allows a set of individuals to communicate rapidly with each other in generating group forecasts and in making policy decisions (Kaynak \& Macaulay, 1984).

\section{Delphi model applied to the South African tourism industry}

\section{Importance and relevance of the study}

The Unit for Marketing Studies at Stellenbosch University launched this project to gather more extensive and reliable data concerning the South African tourism industry's future expansion over the next two decades.

The importance of the study is expressed in the fact that the aggregate nature of available data, mainly on a regional and local level, cannot be used to determine tourism policy decisions at national level. As tourism policy in South Africa differs widely from region to region and indeed even on a local level, it has become important to synthesis information obtained on a regional and local level that could be used on a national level to bridge the disparity which exists. The success achieved by applying this type of research in, for example, Canada (Kaynak \& Macaulay, 1984) and Singapore (Yong, et al., 1988), indicated its usefulness in the South African context.
There are evidently many factors that will influence the future growth and direction of the South African tourism industry, such as: a larger segment of the population having the time and resources to travel; a 'shrinking' world owing to transportation improvements (thereby opening new and/or cheaper tourism destinations to compete with South Africa); increased government recognition of the impact of tourism and its potential revenues; new communications networks, which will allow the global co-ordination of the tourism industry; and the development of 'a new leisure ethic' as a result of changing attitudes towards work, women's roles, affluence and inflation.

To investigate the changing South African tourism industry, projections concerning the social and physical environments as well as a number of scenarios, were investigated. Three broad independent sets of questions pertaining to South Africa were compiled:

- To what extent South African society will undergo changes in their value systems from 1993 through to 2010;

- How the South African tourism industry will undergo changes in its structure from 1993 through to 2010; and What events may have a potential impact on tourism and training in South Africa during the same time span (Bloom \& Leibold, 1992).

\section{Research design and methodology}

A Delphi study involves a number of considerations, including: the selection of panelists; the design of the questionnaire; the provision of feedback; and a decision on the number of rounds to be conducted (Yong, et al., 1988).

The procedure is shown in Figure 1. The panel of experts were selected by knowledgeable international and national tourism analysts for their knowledge of the subject under review. To assure a wide range of ideas and views the selected industry experts were not permitted to interact with each other during the multi-round process. Specific questions to be answered included:

- Does South Africa need a Disney world?

- What levels of tourism does South Africa want, require or may potentially get?

- What impact will future scenarios have on tourism development programmes in South Africa?

- Can political and social harmony culminate in sustainable tourism development?

- What decision should the Ministry of Tourism take with regard to tourism development?

\section{Sample size and panel of experts}

From a scrutiny of relevant research literature it is clear that there is no fixed rule as to the number of experts required to form the Delphi panel, nor is there consensus on the knowledge or expertise required for one to be included as a Delphi member.

The size of Delphi panels reported in past studies covers a wide range from tens to hundreds. The choice depends on the nature, scope and importance of the study. Dalkey (1969) contends that 15 to 20 members is the minimum number of respondents needed. Martino (1983) indicates that expertise and knowledge on the subject matter is the most important 


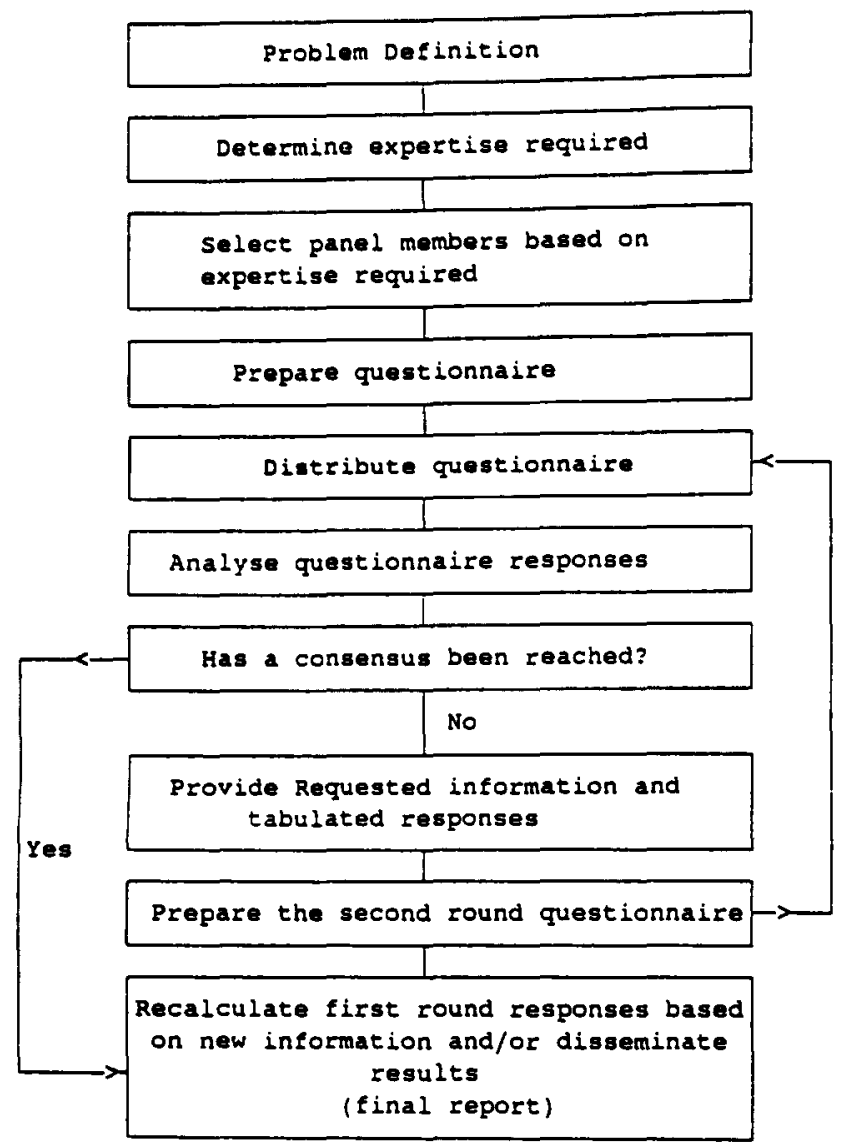

Source: Adapted from Taylor, R.E. \& Judd, L.L. 1989. Delphi method applied to tourism. In Witt, S.F. \& Moutinho, L. (eds.), Tourism Marketing and Management Handbook. Prentice-Hall: Hemel Hempstead, p.96

Figure 1 Delphi research design for the South African tourism study

criterion for a Delphi study. Several published studies, such as Sackman (1975) and Welty (1974) show that high levels of expertise are not necessary for a quality forecast.

To include the wide diversity of industry participants in South Africa it was necessary to compile categories based on a national, regional and in the case of policy makers, on a local level. This panel was classified into eight different categories, namely: policy makers; transportation; accommodation; attractions; travel organizers; industrial and commercial sectors; educators; and industry operators. The list of respondents was submitted to the South African Tourism Board (Satour) who wasof the opinion that the expertise of the chosen respondents was adequate. Satour further indicated which individual person in each organisation had the necessary expertise to provide information on the future of the South African tourism industry.

Although the classification of sectors is of unequal magnitude, participants from both the industrial and commercial sectors who have a direct interest in tourism are also included in an effort to obtain independent viewpoints and predictions.

\section{Questionnaire design and administration}

The questionnaire utilized in the South African study was compiled and significantly adapted by the authors for local conditions and interests, as well as by inputs from knowledgeable personnel in the South African Tourism Board. The original questionnaire was developed by the Canadian Government Office of Tourism (CGOT) and used by them in a Delphi study conducted among industry delegates to a meeting in Toronto in 1981. Kaynak \& Macaulay (1984) further refined and modified the questions used by the CGOT and applied them to the tourism industry in Nova Scotia Canada. The first round questionnaires were mailed to a panel of selected experts (opinion leaders), following a letter of introduction briefly explaining the Delphi method and asking respondents' co-operation in the survey. Stamped, selfaddressed envelopes were included to ensure a higher return rate. A follow-up letter was sent to those not responding within a two-week period.

In the first round a total of 100 questionnaires were distributed and 50 were returned completed, giving a $50 \%$ response rate. Despite the relatively low response rate each category was sufficiently represented. Furthermore, of the experts such as important legislative bodies, industry organisations and industry participants, whose responses carried a heavier weight in the view of the authors, did return completed questionnaires. These respondents were regarded as having the greatest potential to influence the future development of tourism in South Africa.

The mean response was determined for each category. A second questionnaire was distributed to all first-round respondents who completed questionnaires. Altogether 37 of the experts, due to their responses deviating significantly from the mean response, were requested to revise their estimates of the first round, if necessary. A response of $74 \%$ was registered for the second round.

Upon receipt of the completed questionnaires the data was tabulated. The researchers examined each questionnaire to determine the areas and degrees of agreement and disagreement. A composite of responses to the first round questionnaire, along with an explanation of any misconception, formed the basis of the second round questionnaire.

A summary of the results were given to all second-round participants, including a measure of control tendency such as the mean, and a measure of dispersion such as the standard deviation. Comments and concerns raised by the panelists in the first round were distributed for consideration to all the second-round respondents with a view to helping them revise their estimates in the second round, if necessary.

Two rounds were considered to be sufficient as a result of the reduction in variance from average levels of two and three for most of the variables to one and below. This implies that sufficient convergence towards the midrange of the distribution had occurred during the process of reaching group consensus.

\section{Findings}

The first section of the questionnaire was compiled to determine how the tourism experts perceive value changes in South Africa with reference to the development of tourism. The variables examined were those used by CGOT and Kaynak \& Macaulay (1984). However, due to the continuous adaptation and refinement of the value variables they were considered adequate to use, with modification for local condi- 
Table 1 Value changes in South African society 1993-2010.

\begin{tabular}{|c|c|c|c|c|c|}
\hline Variable & Mean & $\begin{array}{l}S D \text { of } \\
\text { mean }\end{array}$ & Median & Mode & $\begin{array}{c}\text { Impact on } \\
\text { tourism }\end{array}$ \\
\hline Traditionalism in work, & & & 4 or & Slight (-) & Moderate \\
\hline family, education & 3.22 & 1.229 & 3.65 & & \\
\hline Hard work as a virtue & 3.02 & 1.250 & 3 or 2.83 & Slight(+) & High \\
\hline Authoritarianism in business & & & 3 or & & \\
\hline desicion making & 3.20 & 1.181 & 3.37 & Slight(-) & Moderate \\
\hline Materialism & 1.80 & 0.757 & 2 or 1.76 & Slight (+) & Moderate \\
\hline Rewarding work & & & 2 or & & \\
\hline as a virtue & 2.47 & 0.960 & 2.28 & Slight(+) & Moderate \\
\hline Individualism & 2.30 & 0.939 & 2 or 2.20 & Slight(t) & Moderate \\
\hline Individual involvement & & & 2 or & & \\
\hline in society & 2.45 & 0.985 & 2.19 & Slight & Moderate \\
\hline Participation in decision- & & & 2 or & & \\
\hline making in business & 1.72 & 0.816 & 1.61 & Significant(t) & High \\
\hline Self expression & 2.12 & 0.965 & 2 & Slight(t) & High \\
\hline Acceptance of change & 1.42 & 0.500 & 1 or 1.67 & Significant(+) & Highets \\
\hline
\end{tabular}

Notes:

a.Five point scale was used where $1=$ significantly increase; $2=$ slight increase; $3=$ no change; $4=$ slight decrease; $5=$ significant decrease. $b$. This indicates the degree of impact that the value changes in South African society will have on tourism: $0=$ not important; $10=$ critically important. Under the impact of tourism 4 to 5 signifies medium, 5 to 6 moderate, 6 to 7 high and above 7 highest; $(-)=$ decrease; $(+)=$ increase.

tions, in the South African study. With the developments taking place in the country a positive change, for example, in the variable, 'participation in decision- making in business', may result in decision-makers from all population groups deciding on a equitable range of facilities and attractions for all tourism participants. The ten variables indicated in Table 1 includes a variable authoritarianism in business decision-making, not included by the CGOT or Kaynak \& Macaulay (1984).

Overall, the experts foresee little change in basic value systems of South African society over the next 18 years. Any slight change in these variables would have a moderate impact on tourism development. However, hard work as a virtue and self expression, it would appear, could have a high impact on tourism even with a slight change in the status quo. Considering the numerous changes taking place in South Africa at present, it could be expected that changes with regard to participation in decision-making in business and the acceptance of change could be significant, while having a considerable impact on tourism.

The second part of the study requested respondents to give their notion as to how the structure of the South African tourism industry is likely to change between now and the year 2010 and to specify what impact any change would have on the industry itself. There was a total of 31 variables including a category for 'other' variables not stated in the table. These variables included, amongst others, types of accommodation, food and beverage outlets, types of travel attraction and events, as shown in Table 2 . In all the variables but five, respondents foresee only slight change or no change at all. With the changing infrastructure of South African tourism respondents believe that hotels, guest homes and bed and breakfast accommodation will become increasingly popular due to increased tourist potential. Due to domestic air traffic deregulation and the improved political situation respondents see a significant increase in airline traffic, with a considerable change taking place regarding tour operator business due to a phenomenal increase in tourist arrivals expected over the next two decades. It would appear that the need for information on a regional basis in South Africa could substantially increase, hence the significant changes expected regarding publicity associations.

If one considers the impact that these variables may have on tourism, it is evident that any slight change could heavily impact on tourism. In the South African context the role of the government in tourism is becoming increasingly important with hopes that a new South African government would make tourism a high priority by providing adequate and goaldirected incentives and funds. In this regard attempts to direct the development of the tourism industry into an integrated whole, where each industry participant is seen as a viable and necessary component, could be a major policy objective. It would appear that accommodation establishments, transportation, operators, and attraction operators could experience significant increases in business with a multiplying effect for the industry as a whole.

The third part of the study expressed a number of event statements or scenarios to access the panelists' perceptions of the likelihood of occurrence of each event from 'never' to ' $100 \%$ '; the year of probable occurrence from '1993' to '2010 or beyond'; and the importance of the event to tourism training in South Africa on a ten-point scale from 'not important' to 'critically important' (Bloom \& Leibold, 1992). The results are shown in Table 3.

The 43 statements were meant to project the future scenario of the South African tourism industry by seeking the panelists' collective views on such as: the future trends in the pursuit of 
Table 2 Changing structure of the South African tourism industry 1993-2010

\begin{tabular}{|c|c|c|c|c|c|}
\hline Variable & Mean & SD of mean & Median & Mode & $\begin{array}{l}\text { Impact on } \\
\text { tourisim }\end{array}$ \\
\hline Hotels & 1.61 & 0.846 & 1 or 1.47 & Significant $(+)$ & Highest \\
\hline Casino hotels & 1.65 & 0.662 & 2 or 1.61 & Slight(+) & High \\
\hline Timc share & 2.65 & 0.921 & 2 or 2.44 & Slight(+) & Moderate \\
\hline Resorts & 1.70 & 0.686 & 2 or 1.69 & Slight(t) & Highest \\
\hline Guest homes and bed & & & 1 or & & \\
\hline \& breakfast est. & 1.26 & 0.501 & 1.16 & Significant(+) & Highest \\
\hline Farm vacations & 1.82 & 0.675 & 2 or 1.83 & Slight(+) & Moderate \\
\hline Campgrounds, & & & 2 or & & \\
\hline caravan parks & 2.65 & 1.051 & 2.44 & Slight(+) & Medium \\
\hline Cottage and & & & 2 or & & \\
\hline vacation homes & 1.90 & 0.700 & 1.87 & Slight(+) & Moderate \\
\hline Fast-food outlets & 1.60 & 0.590 & 2 or 1.60 & Slight(t) & Medium \\
\hline Airlines traffic & 1.09 & 0.300 & 1 or 1.05 & Significant $(+)(c)$ & Highest \\
\hline Inter-city bus & & & 2 or & & \\
\hline lines traffic & 1.70 & 0.642 & 1.69 & Slight(+) & High \\
\hline Rail service & 2.63 & 0.829 & 3 or 2.58 & None & Medium \\
\hline Retail sporting goods and & & & 2 or & & \\
\hline recreational equipment stores & 2.07 & 0.655 & 2.03 & Slight (+) & Medium \\
\hline Gift shops & 1.77 & 0.619 & 2 or 1.80 & Slight(+) & Moderate \\
\hline Duty free shops & 132 & 0.764 & 2 or 1.91 & Slight(+) & Moderate \\
\hline Travel agencies & 2.31 & 1.010 & 2 or 2.10 & Slight(t) & Moderate \\
\hline Tour operators & 1.65 & 0.824 & 2 or 1.50 & Significant(+) & Highest \\
\hline Theme developments & 1.82 & 0.675 & 2 or 1.83 & Slight(+) & High \\
\hline Historic sites \& & & & 2 or & & \\
\hline monuments & 2.42 & 0.957 & 2.32 & Slight(+) & Moderate \\
\hline National and provincial & & & 2 or & & \\
\hline parks (i.e. Kruger Park) & 1.75 & 0.707 & 1.72 & Slight(+) & Highest \\
\hline Local entertainment- & & & 2 or & & \\
\hline establishments & 1.75 & 0.588 & $1: 79$ & Slight(+) & High \\
\hline Personal services & 1.79 & 0.767 & 2 or 1.78 & Slight (+) & High \\
\hline Cultural and & & & 2 or & & \\
\hline educational attractions & 2.00 & 0.716 & 1.97 & Slight (+) & High \\
\hline Cruise ship traffic & 2.04 & 0.835 & 2 or 1.95 & Slight (+) & Moderate \\
\hline Museums & 2.65 & 0.668 & 3 or 2.75 & None & Medium \\
\hline Festivals \& event & & & 2 or & & \\
\hline attractions & 1.67 & 0.525 & 1.74 & Slight (+) & High \\
\hline Passenger car traffic & 1.57 & 0.549 & 2 or 1.59 & Slight(+) & High \\
\hline Bus tours & 1.55 & 0.552 & 2 or 1.55 & Slight(+) & Highest \\
\hline Government involvement & & & 2 or & & \\
\hline in tourism & 2.10 & 1.104 & 1.88 & Slight(t) & High \\
\hline Publicity association & 1.87 & 0.852 & 2 or 1.78 & Significant(+) & High \\
\hline \multicolumn{6}{|l|}{ Others ${ }^{c}$} \\
\hline \multicolumn{6}{|l|}{ Notes: } \\
\hline \multicolumn{6}{|c|}{$\begin{array}{l}\text { a. Five point scale was used where } 1=\text { significantly increase; } 2 \text { =slight increase; } 3=\text { no change; } 4=\text { slight decrease; } 5=\text { sig- } \\
\text { nificant decrease. }\end{array}$} \\
\hline \multicolumn{6}{|c|}{$\begin{array}{l}\text { b. This indicates the degree of impact that the changing structure of the South African tourism industry will have on tourism: } 0 \\
=\text { not important; } 10=\text { critically important. Under the impact of tourism } 4 \text { to } 5 \text { signifies medium, } 5 \text { to } 6 \text { moderate, } 6 \text { to } 7 \text { high } \\
\text { and above } 7 \text { highest; }(-)=\text { decrease; }(+)=\text { increase. } \\
\text { c. Other factors indicated by the experts that could have a slight or significant increase in the structure of the South African tour- } \\
\text { ism industry and a high impact on South African tourism are indicated as follows: Charter flights; Tourism study and educa- } \\
\text { tion; Tourism marketing; Formation of regional tourism bodies. }\end{array}$} \\
\hline
\end{tabular}

leisure and travel activities; the technological advances which will have an impact on the tourism industry; the future international travel environment; regional collaboration in the future; South Africa as a future tourist center; tourism training and future political environment and travel restrictions within the region.
The panelists saw every scenario as being possible although some had a low probability of occurrence. What is important is that the respondents believe all the scenarios are probable within the specified time period. The most significant events, however, are those that were seen to have a high probability of occurrence within the next decade (1993-2003) and having a 
Table 3 Events having potential impact on tourism and training (continues)

Event
The 30 hour work week and annual month-long vacations charaterize the normal work patterns in developed countries.

Over $80 \%$ of North American and a majority of Western European and Japanese households will have a specific family budget for travel and leisure pursuits.

For these same households travel and tourism will be non-discretionary expenditures.

Half of the working population in urban centres throughout the world works primarily for life fulfillment rather than economic necessity.

Completely new frontiers are open to tourism (sea and underwater environments, underground environments and wilderness environments).

Air taxis to locations within 200 miles are integrated with major metropolitan airports in developed countries.

Border formalities (e.g. requirements, visa, customs) of most countries are relaxed.

An international data bank with video of real-time communication is established for tourist information.

A network of international travel routes of most natural carriers is established.

Inexpensive long haul (over 100 miles or $167 \mathrm{~km}$ ) mass stransport by water is feasible.

Liberalization of international airline agreements makes travel movements between East and West, North and South almost as easy as within countries of the West.

Automation replaces most laborintensive administration and industrial jobs in the urban areas throughout the world.

Most people travel on other continents as commonly as in their own country today.

Major technological advances lower intemational travel costs to prices affordable on a middle-class budget.

Much business travel is replaced by video conferencing technologies and other forms of telecommunication (e.g. satellites, teleconferencing, viewphones, etc.)

Fully automated data retrieval systems are developed on a global basis to provide travel information in real-time.

Public and private sectors work together through educational and cultural projects to reduce hostility towards international tourists.

The world energy problem will have been solved.

At least $50 \%$ of the world's monetary transactions occur through computerized credit, audit, buying and billing systems.

Artificial environments are commonly used for outdoor recreation facilities and areas to provide tourism opportunities.

The dominant proportion of food served in non-fast food restaurants will be prepared in centralized kitchens.

A majority of hotels will be self-service rather tha the present conventional style of hotel.

Over 10 million people participate in timessharing (reson) condominiums throughout the world.

An international currency is used for monetary exchange among nations of the wordl.

Very effective programs in most countries establish economic incentives to private industry for the protection of wildlife, scenic beauty and natural environments.

Limited access to natural resources is achieved by (a) rationing, (b) drawing lots and (c) residential qualifications.

The majority of people employed in the tourism industry in South Africa will be of nonEuropean origin.

The dominat proportion of restaurant food sales income will come from fast food outlets.

Hotel and restaurant managers will require more specialized and formal types of educational programs.

Many universities and colleges in South Africa would integrate tourism and hospitality degree programs in their curriculum.

Demand for part-time training programs for people who are currently employed in the hospitality industry will increase substantially.

The African continent is becomimg a major tourist destination of the world.

South Africa is successfully accepted as a single travel destination.
$\mathrm{A}(\%)$

$39.5 \%$

$1999-2000$

Moderate

$60.5 \%$

1997-1998

$40.0 \%$

1999-2000

Critical

$24.7 \%$

1999-2000

High

$57.7 \%$

2001-2002

Moderate

$56.7 \%$

2001-2002

Highest

$68.0 \%$

1999-2000

High

$73.7 \%$

1999-2000

Highest

$73.7 \%$

1997-1998

Highest

$73.0 \%$

2001-2002

Highest

$41.0 \%$

1998-1999

Medium

$70.5 \%$

Highest

$50.2 \%$

2003-2004

Moderate

43.7\%

2001-2002

High

$60.7 \%$

$2001-2002$

Highest

2003-2004

Moderate

$71.5 \%$

$1999-2000$

Highest

$60.7 \%$

1999-2000

Highest

$24.2 \%$

2003-2004

Moderate

$71.0 \%$

1999-2000

High

2001-2002

Moderate

$38.7 \%$

2001-2002

Medium

$47.0 \%$

2001-2002

Moderate

$52.2 \%$

2001-2002

Moderate

$39.7 \%$

2003-2004

Moderate

$73.5 \%$

2001-2002

Critical

2001-2002

High

$72.5 \%$

1999-2000

Moderate

$61.2 \%$

1999-2000

Moderate

$72.0 \%$

1997-1998

Highest

$69.5 \%$

1999-2000

Highest

$78.2 \%$

1995-1996

Critical

$58.2 \%$

2001-2002

Critical

$60.5 \%$

1999-2000

Critical 
sion-making forums, and a clear demarcation of the roles of national, regional and local level tourism bodies to facilitate interaction and co-ordination through the relevant mechanisms (Satour and Development Bank of Southern Africa, 1991). There seems to be an increasing realization that South Africa and adjcining countries form part of a regional (subcontinent of Africa) tourism destination, and it is likely that regional tourism organisations and co-operative mechanisms will be either improved or instituted in the near future.

\section{Business profile}

To obtain relevant demographic data, the final section of the questionnaire requested details on the type of business involved and their geographical location. The largest portion of the respondents were from the Western Cape area of South Africa. The biggest category of respondents formed part of the transportation and travel organiser sector, followed by the policy makers at national, regional and local level. The profile is shown in Table 4.

\section{Conclusions}

The application of the Delphi technique as a marketing research tool in the South African tourism industry has provided a number of significant findings and indicators of the likely future tourism scenario of the country. The Delphi technique has several advantages in tourism forecasting, especially to identify consensus questions and issues critical to desirable change in the future. The major limitations of the study is that expert opinions are more reliable for aggregate forecasting of likely tourism occurrences and trends.

Concerning basic value systems and value changes in the South African society toward the year 2010, the indicators are disappointing, as only little or moderate change are foreseen. Those values which potentially have the highest impact on tourism, such as hard work as a virtue, self-expression, and acceptance of change need to be particularly addressed as they could have a significant positive result on the tourism industry.

It is evident from the findings concerning the future tourism industry structure that particular attention would have to be directed to certain sectors of the tourism industry. These sectors are specific types of attractions (e.g. parks/reserves, festivals and events, theme developments) accommodation establishments (hotels, bed \& breakfast, guest homes), transportation facilities (airline traffic, including airports), tour and travel services, and tourist information. It is heartening that the results of the study indicate that significant positive changes are foreseen towards the year 2010 in these structural variables of the tourism industry. However, it would be important for all industry structure variables to be considered in conjunction, and that Government (on all levels) provide both the climate and appropriate incentives for structural improvements.

Finally, from the results of an extensive number of event statements, it can be concluded that the realization of the optimum potential of the South African tourism industry in the first decade of the 21 st century would depend on goaldirected, professional tourism education and training, effective and efficient co-ordination and co-operation of tourism efforts nationally and regionally, and the appropriate imple- mentation and utilization of information technology and its output.

\section{References}

Archer, B. 1980. 'Forecasting demand - quantitative and intuitive techniques', Tourism Management, Vol. 1, No. 1: 5-12.

BarOn, R. R. 1979. Forecasting tourism - theory and practice. TTRA, Tenth Annual Conference Proceeding, College of Business University of Utah, Utah.

Bloom, J.Z. \& Leibold, M. 1992. Determining the future South African tourism scenario by use of the Delphi technique as a market research tool. Paper read at the Marketing Educators Conference, Cape Town.

Chambers, J.C. 1971. 'How to choose the right forecasting technique', Harvard Business Review, Vol. 49, No. 4: 45-81.

Dalkey, N.C. 1969. Delphi method: an experimental study of group opinion. USA: The Rand Corporation,

Dull, R. 1988. 'Delphi forecasting: marketing research method of the 1990's', Marketing News, Vol. 22, 29 August: 17.

Dyck, H.J. \& Emery, G.J. 1970. 'Social futures Alberta 1970-2005', Human Resources Research Council of Alberta, Canada: Edmonton.

Edgell, D.L., Seely, R.L. \& Iglarsh, H.J. 1980. 'Forecasts of international tourism to the USA', Intemational Joumal of Tourism Management, Vol. 1, No. 2: 109-113.

Gearing, C.E ., Swart, W.W. \& Var, T. 1976. Planning for tourism development: quantitative appmaches. New York: Praeger.

Heath, E. 1992. An overview of the South African tourism industry with specific reference to the strategic framework for tourism development and the Government's White Paper on tourism. An address delivered at the AIC conference. Sandton, Johannesburg.

Jolson, M.A. \& Rossow, G.L. 1971. 'The Delphi process in marketing decision making', Journal of Marketing Research, Vol. 8: 443-448.

Kaynak, E. \& Macaulay, J.A. 1994. 'The Delphi technique in the measurement of tourism market potential', Tourism Management, Juned:: 87-101

Kibedi, G. 1981. 'Future trends in international tourism', Tourism Review, Vol. 36, No. 1: 3-6.

Lavoie, E. 1985. 'Future trends in financing municipal recreation in Nova Scotia', Proceeding of the Recreation Research Symposium: 28-33.

Linstone, H. A. \& Simmonds, W. H. C. 1977. Future research:new directions. London: Addison- Wesley.

Lusch, H.A. \& Laczniak, G.R. 1979. Futures research for managers. Business, Vol. 29, No. 1: 41-49.

Martino, J.P. 1983. Technological forecasting for decision making, New York: American Elsevier.

Ministry for Administration and Tourism. 1992. White Paper on Tourism. (ISBN 086485-363-7), Pretoria: Government Printer.

Moeller, G.H. \& Shafer, E.L. 1983. 'The use and misuse of Delphi forecasting'. In Lieber, S.R. \& Fesenmaier (Eds.). Recreation Planning and Management, London: E \& F.N. Spon: 96-104.

$\mathrm{Ng}$, D. 1984. 'A model estimating the demand for leisure services manpower', World Leisure and Creation, Vol. 26, No. 5: 45-49.

Paliwoda, S.J. 1983. 'Predicting the future using Delphi', Management Decisions, Vol. 21, No. 1: 31-38.

Ryan, C. 1992. 'Tax breaks to boost tourism', Business Times, August, 1, 3 .

Sackman, H. 1975. Delphi critique: expert opinion, forecasting and group process. Massachusettes: D. C. Heath, Lexington.

Satour and Development Bank of Southern Africa. 1991. A strategic framework for tourism development in Southern Africa. Pretoria.

Seely, R.L \& Iglarsh, H.J. \& Edgell, D. 1980. 'Utilizing the Delphi technique at international conferences: a method for forecasting international tourism conditions', Journal of Travel Research, Vol. 
1: 30-36.

Taylor, R.E. \& Judd, L.L. 1989. 'Delphi method applied to tourism', In Witt. S.F. \& Mountinho,L. (Eds.). Tourism marketing and management handbook. Hemel Hempstead, Prentice-Hall: 95-98.

Uysal, M. \& Crompton, J.L. 1985. 'An overview of approaches used to forecast tourism demand', Journal of Travel Research, Vol. 23, No. 4: 7-15.

Van Zyl, C.J. 1990. The mle of historic preservation in the promotion of tourism. A paper read at the Urban Conservation Symposium. Session: Tourism and Finance, Johannesburg.

Welty, G. 1974. 'Problems of selecting experts for Delphi exercises',
Academy of Management Journal, Vol. 15: 121-124.

Wheatly, K.L. \& Flexner, F.W. 1987. 'Research tool changes the way marketers view data', Marketing News, Vol. 21, No. 5: 23.

Witt, S.F. \& Mountinho, L. 1989. Tourism marketing and management handbook. Prentice-Hall: Hemel Hempstead.

Woessner, C. 1992. The South African domestic tourism market. (Job No. 92/193/CW/ge), Johannesburg: Markinor (Pty) Limited.

Yong, Y.W., Keng, K.A. \& Leng, T.L. 1988. 'A Delphi forecast for the Singapore tourism industry: future scenario and marketing implications', International Marketing Review, Vol. 6, No. 3: $35-46$. 